\title{
Prunus africana Provenances Growth and Survival Evaluation in the Highland of Awi zone, Amhara Region, North Western Ethiopia
}

\section{Abraham Demekristos \\ Hawassa University, Wondo Genet College of Forestry and Natural Resources, Mobile: 0918801040, Email:abr2030@yahoo.com, Hawassa, Ethiopia}

\begin{abstract}
The aims of the study were to evaluate seedling growth and survival of Prunus africana provenances in awi highland based on ecological requirement of the tree.

We measured survival and growth of three P.africana provenances seedlings found in Ethiopia (provenances sources namely: Gedeo, Jibat and Munnessa). Design of experiment with randomized complete block design (RCBD) with three replications. Seedlings planted at $2 \mathrm{~m}, 2.5 \mathrm{~m}$ and $3 \mathrm{~m}$ distance between plants, plot, and blocks respectively. A plot size of $10 \mathrm{mx} 10 \mathrm{~m}$ and 25 plants are found per plot (0.01ha).

We used ANOVA to test differences in survival, and growth among provenances over time.

Results concluded that, provenances have no significant variation among in establishment rate, plant height and collar diameter growth. Of these provenances, Jibat was the first in establishment $(56 \%)$, second in height $(1.97 \mathrm{~m})$ and diameter $(2.89 \mathrm{~cm})$. Gedeo was stood first in height $(2.30 \mathrm{~m})$ but second in establishment rate $(52 \%)$ and thickness $(3.45 \mathrm{~cm})$, but Munessa with very good growth in diameter $(3.59 \mathrm{~cm})$ might be prefreed for bark extraction followed by Gedeo, last in height $(1.75 \mathrm{~m})$, but established second $(52 \%)$. Contrary to expectations, seedlings were still at substantial risk of mortality $\geq 3$ years after planting. Probably the plants survival rate and growth probably affected by altitude, soil water potential, light exposure, and wild animal presence in the surrounding. In steep slope sites, canopy shade, existing weed vegetation as well as wild animals such as apes is unlikely to enhance seedling survival after planting.

Our results suggest that seedling mean growth increased with $0.008 \mathrm{~mm}$ thickness and $0.41 \mathrm{~mm}$ per day while $2.8 \mathrm{~mm}$ thickness and $146.8 \mathrm{~mm}$ tall increment recorded in $2560 \mathrm{~meter}$ elevated high land or injibara with mean value of $18.5^{\circ} \mathrm{C}$ and rain fall is $1300 \mathrm{~mm}$.
\end{abstract}

Keywords: provenances, height, root-collar-diameter, survival, growth

\section{Introduction}

Prunes africana (locally known as $\square \square \square \square \square \square \square / T i k u r$ Inchet, Aqoma(Amh); African cherry, Bitter almond, Red ivory, Iron wood, Red Stinkwood(Eng), in the family Rosaceous, 
is the only sub-Saharan African montage forest species(Betti,J.L.,2008). It is found naturally from Ethiopia in the north, down to South Africa, as distant west as Nigeria and as extended east as Madagascar (Walter and Rokonirina 1995). The Honeybee flora of Ethiopia reports that it require rainfall of 1000-2000 mm per year and can be found from 1550-3100m asl. The Seed of $P$. africana is recalcitrant, which means that unless seeds are planted shortly after collection their germination rate will drop markedly (Fight R. and Aid A., 1994). P. africana has been identified as top priority internationally for conservation and development because of its bark. The bark extracts are used to make capsules for benign paratactic hyperplasia. The bark was traditionally powdered and drunk as a tea for genitor- urinary complaints, allergies, inflammation, kidney disease, malaria, stomachache, and fever, among other uses (Cunningham and Mbenkum 1993). Folkloric use in Africa attracted the attention of European researchers, and a patent was issued in 1966 for use of a pigeon bark extract in the treatment of benign prostates hyperplasia (BPH).

P.africana are multi-purpose tree in Ethiopia used for bridge decking (local), heavy construction, excellent firewood and valuable pollen and bee forage, charcoal, traditional medicines (leaves, bark etc.), shade, ornamental, windbreaks, mulch, green manure, and is also very suitable for making furniture made from the very durable wood (Fichtl \& Admasu, 1994).

P. africana is widespread in montane (1550-3100m) and riverine forests (1700-2500m) of Haraghe, Kefa, Ilu Ababor, Sidamo, Arsi, Wolega, Gojam, Gonder and Shewa regions (Dawit Abebe and Ahedu Ayehu, 1993). Its habitat is moist evergreen forest of mountain, mist belt areas/ montane tropical forest; often in riverine vegetation or on forest margins and in remnant patches (Cunningham and Mbenkum, 1993).

Resource assessment and few field studies indicated there is high forest resources coverage in amhara national regional state estimated about $5.91 \%$. Another assessment by beauro of agriculture(BoA) was $0.48 \%$ natural high forest, $4.2 \%$ woodland, and $1.23 \%$ plantation forests (Bane et al. 2008).even if no quantitative study conducted on P. Africana, there is high wild forests, particularly Awi zone has been potentially rich. However, due to Habitat destruction and fragmentation (Agricultural expansion), deforestation and mismanagement of dry and moist afromontane forest ecosystems threat are among the major factor in Ethiopia. This has serous implication for P.african no longer occur in Ethiopia even in dispersed wild areas where there may be as many as a thousand species. Uniquely the species seed behavior recalcitrant, sun exposure and intolerable desiccation due deforestation reduced regeneration, 
and unable to store seed in ex situ conservation. This study aimed to determine best provenances in survival and growth, responds to in their ecological ranges, and to elucidate the value of environments to adaptation at moist montane field as a methods of in situ conservation strongly appreciated to save the species from disappearance as recommended by Cunningham and Mbenkum (1993).

\section{Objective:}

- To evaluate the survival rate and growth of Prunus africana provenance in moist montane forest

- To conserve the species through in situ in its ecological range

\section{Materials and methods}

\subsection{Study site}

The experiment was conducted from august 2007 to 2011 in Injibara at Banja District, in Awi zone of Amhara region, found in north western Ethiopia. The district is located at latitude of $11^{\circ} 10^{\prime}$ north and longitude of $36^{\circ} 15^{\prime}$ east and $122 \mathrm{~km}$ far from the regional city Bahir Dar to south and $447 \mathrm{~km}$ north to Addis Ababa. Experimental site Injibara in particular is administrative town of Awi zone, the town was constructed since 1991 at a place called Kosober by locals, at the junction of Highway three from Addis Ababa to Bahir Dar and the road leading west towards Chagni and into Metekel Zone.

The average elevation of the district is $2560 \mathrm{~m}$ above sea level and the mean annual temperature and rain fall is $18.5^{\circ} \mathrm{C}$ and $1300 \mathrm{~mm}$, respectively. The district is classified into one agro climatic zone, which is high land with wet and cool weather condition (Tegegne Melese, and et al., 2015).

\subsection{Source of provenances}

Three different provenances were collected from different montane forest regions of Ethiopia namely; Gedeo (SNNP), Jibat and Munnesa (Oromiya) hereafter referred to by their collected local names were selected because of their significant ecological and economic importance. The provenances were collected by the Institute of Amhara Agricultural Research (ARARI) and seedlings raised in Adet agricultural research center nursery. Seedlings raised in nursery and carried out plantation for the establishment of the experiment. Representative sites selected based on ecological requirement of the tree with rough estimate $>70 \%$ sloppy hill for the experiment is secured at Banja Shekudad district. Tree-shrub and mainly decurenceforest edges cleared out to allow access for many management issues. 
Planting pits prepared and this was done approximately weeks before the onset of the rainy season. Only available unequal sized seedlings were planted due shortages to be counted 25 obtained from the center nursery. The seedlings were planted in depth of soil moisture enough, which carried out in august first week with after continuous rain. The field lay out was arranged in randomized complete block design explained as follows:

\subsection{Experimental Design}

Growth and survival of seedlings of Prunus africana provenances were investigated in a moist tropical montane forest under natural environment in randomized complete block design (RCBD) design. The RCBD experiment was established in the first week of August 2011. The study conducted over 1,854days or 5 years and 29days old from 20011 to 2015. The design of the experiment was laid in a randomized block design with three replications. Seedlings planted at 2 meter distance between the plants in a plot, $2.5 \mathrm{~m}$ distance between the plots in a block and $3 \mathrm{~m}$ distance between the blocks with a plot size of $10 \mathrm{mx} 10 \mathrm{~m}$. 25 plants are found per plot (0.01ha) and with a density of about 2,500 plants per hectare. The distance between the two rows should also be 2 meters. This spacing will accommodate 2500 plants/ha. The trial site covers about 0.12 hectare $(35 \mathrm{~m} \times 35 \mathrm{~m})$.

\subsection{Seedling growth experiment}

Reserved seedlings of Prunus africana from the nursery were transported and transplanted to the experimental plots. After plantation, growth data, weeding and other follow up begin after 3 months. After a period of 3months growth data collection started, and in every 6 months interval the collection continued till 5yeras and 29days. Growth data such as plants height, root collar diameter, pest incidents, survival rate as well as other observation data in each plot was recorded in every 6 months interval for the last five years. Sample seedlings not less than 10plants taken diagonally to increase representativeness in the plot as well as to avoid mechanical damages particularly boundary plants excluded in the sample.

Plants at experimental field were weeded when weeds emerged depending on rain fail that enhance weeds. Regeneration of some trees and shrubs especially Acacia decurrence clear out when ever sprouted and needed.

\subsection{Analysis of growth performance}

Seedling Growth parameter response mainly height abbreviated in (HT), diameter considered as root collar diameter (RCD) under different provenances. One way ANOVA was used to test growth differences among provenances over time. 
We used regression (and p-value) in Microsoft excel to test whether relative seedling height and thickness growth rates correlations. Relative growth rate of seedlings was calculated following the convention of Alvarez-Aquino et al. (2004) the heights of the seedling at initial planting and upon measurement three months later, respectively. In this study, time was measured in years.

\section{Results}

\subsection{Seedling Survival}

Difference in the survival rate was not significant at $\mathrm{P}=0.05$ among provenances at all the five years (Table 1). Survival decreased over time, and mainly provenances had lowest survival ( $<60 \%$ the national average). At the age of five year after planting, the provenance seedling survival rate ranged between $52 \%$ and $56 \%$ with the overall mean survival rate of $53.33 \%$.

After five years of planting, the highest survival was shown by provenances come from around Jibat (56\%) and the lowest by Gedew (52\%) and Munessa (52\%) respectively. The survival of provenances comes from Jibat and Munessa are almost same. However, seedling survival and growth performance under nearby forest canopy shades which probably slight determinants on growth performance and survival especially in the early establishment. Our observation indicates that too steep slopes flooding also reduced seedling survival.

Table1. Mean survival rate (\%) of Prunus africana provenances at Injibara

\begin{tabular}{llllll}
\hline Provenances & \multicolumn{7}{l}{ Age/years after planting } \\
\hline & 1 & 2 & 3 & 4 & 5 \\
Gedeo & 100 & 100 & 60 & 52 & 52 \\
Jibat & 100 & 100 & 80 & 76 & 56 \\
Munnesa & 88 & 88 & 56 & 52 & 52 \\
Mean & 96 & 96 & 65.33 & 60 & 53.33 \\
Anova provenance & $\mathrm{ns}$ & $\mathrm{ns}$ & $\mathrm{ns}$ & $\mathrm{ns}$ & $\mathrm{ns}$ \\
\hline
\end{tabular}

Note: $n s=$ not significant at $(P=0.05)$.

After one and two years of planting, Gedeo, and Jibat were consistently maintained the highest $(100 \%)$ survival rate, whereas Munnessa showed the lowest (88\%). After three, and four years of planting, there were survival changes in all provenances. However, Jibat attained the highest survival rate $(76 \%)$ while provenances come from Gedeo and Munnesa showed same survival rate and showed the lowest (52\%). Similarly, at the age of five years, there was no significant change in mean survival rate within and among provenances. At this 
age, Jibat still maintained the highest 52\% survival rate while Gedeo and Munnessa showed the lowest (52\%), and the overall mean was $53.33 \%$ (Table 1).

Survival is the most important variable to be considered in plantation establishment, besides the growth character of provenances. The long-term yield of plantation per unit area can be affected by the mortality or survival of trees (Negash and Mebrate, 2005). In this context, the results showed that the survival rates of all provenances were good and but not as expected over the whole five years at Injibara site condition. The overall survival rate was varied from 96\% to $53.33 \%$. The good performance of all P.africana provenances at the study site implies that higher survival rate may be achieved if those provenances are used as a seed sources and their seedlings are properly raised, planted, and protected from weed competition.

Seedling increment over five years, particularly in days, months and years was analyzed after five years age field planting. Mean height and root collar diameter (diameter) divided by growth durations produced results as shown in table 2 .

Table 2: Prunus africana seedling means growth over 1854days period and provenance

\begin{tabular}{lllllll}
\hline $\begin{array}{l}\text { Provenances } \\
\text { (locality) }\end{array}$ & \multicolumn{3}{l}{$\begin{array}{l}\text { Mean height } \\
\text { increment }(\mathbf{m m}) \text { per }\end{array}$} & \multicolumn{4}{l}{$\begin{array}{l}\text { Mean root collar } \\
\text { diameter } \\
\text { increment }(\mathbf{m m})\end{array}$} \\
\cline { 2 - 8 } & Year & Month & Day & Year & $\begin{array}{l}\text { Mont } \\
\text { h }\end{array}$ & Day \\
Gedew & 154.80 & 12.90 & 0.43 & 2.64 & 0.219 & 0.0073 \\
Jibat & 147.60 & 12.30 & 0.41 & 2.74 & 0.228 & 0.0076 \\
Munnessa & 137.90 & 11.50 & 0.38 & 3.024 & 0.252 & 0.0084 \\
mean & 146.77 & 12.3 & 0.41 & 2.8 & 0.233 & 0.0078 \\
\hline
\end{tabular}

As it can be showed at table 2, after 1856 days after planting generally mean height increment of $146.77 \mathrm{~mm}, 12.3 \mathrm{~mm}$, and $0.41 \mathrm{~mm}$ ) and mean root collar diameter(diameter) increment of $(22.8 \mathrm{~mm}, 0.23 \mathrm{~mm}, 0.0078 \mathrm{~mm})$ per year, month and day, respectively. This mean growth calculation will help to understand for users and determine expected growth of the species P.africana in similar climate of Injibara areas.

\section{Height growth}

Test result indicated us, there was high significant in height growth across each respective years after planting at $((\mathrm{P}>0.00001$, where $\mathrm{p}<0.05$, alpha $=0.05)$. but, none significant among provenances $(\mathrm{P}>0.0534)$. However, among the tested provenance, Jibat attained the top rank 60months/1854days or five years after planting that followed by Gedeo and Jibat, respectively. After 1854days of planting the overall mean height growth was $2.01 \mathrm{~m}$ (Table $3)$. 
Table 3. Mean height (m) of Prunus africana provenances at Injibara.

\begin{tabular}{llllll}
\hline Provenances & \multicolumn{7}{l}{ Age/years after planting } \\
\hline & 1 & 2 & 3 & 4 & 5 \\
Gedeo & 0.49 & 0.68 & 1.00 & 1.94 & 2.30 \\
Jibat & 0.49 & 0.83 & 1.21 & 1.66 & 1.97 \\
Munnesa & 0.34 & 0.63 & 0.96 & 1.48 & 1.75 \\
Mean & 0.44 & 0.72 & 1.06 & 1.69 & 2.01 \\
Anova provenance & $\mathrm{ns}$ & $\mathrm{ns}$ & $\mathrm{ns}$ & $\mathrm{ns}$ & $\mathrm{ns}$ \\
\hline
\end{tabular}

In general, mean height growth over years showed significance increment. This may be attributed to more or less to altitudinal similarity between Gedeo (1268 m.) and provenance from Jibat $(2500 \mathrm{~m})$ while the site is may be too high in elevation or altitude for provenance from Munnessa (2400m a.s.1.). In addition effect of other variables for all the three provenances, probably evidences of weed, shade, soil water potential, and presences of wild apes on the site were common variables explaining height growth variation over years.

\section{Root Collar diameter}

Mean root collar diameter at all age is presented in Table 4. Provenances were not showed significant differences in root collar diameter.

Table 4. Mean Root collar diameter (cm) of Prunus africana provenances at injibara.

\begin{tabular}{llllll}
\hline Provenances & \multicolumn{7}{l}{ Age/years after planting } \\
\hline & 1 & 2 & 3 & 4 & 5 \\
Gedeo & 0.55 & 0.94 & 1.53 & 3.21 & 3.45 \\
Jibat & 0.57 & 1.18 & 1.64 & 2.85 & 2.89 \\
Munnesa & 0.52 & 0.97 & 1.99 & 3.06 & 3.59 \\
Mean & 0.55 & 1.03 & 1.72 & 3.04 & 3.31 \\
ANOVA provenance & $\mathrm{ns}$ & $\mathrm{ns}$ & $\mathrm{ns}$ & $\mathrm{ns}$ & $\mathrm{ns}$ \\
\hline
\end{tabular}

Note: $n s=$ not significant at $(P=0.05)$.

Our null hypothesis states that there are no differences among the provenance in root collar diameter increment based on year's age after planting. So based on our result, we fail to reject that null hypothesis: there is no evidence that the provenance seedlings thickness mean differ in any significant way.

However, relatively provenance from Jibat attained the highest root collar diameter growth at the age of one and two years but the least at the age of four and five years. Provenance from Munnessa showed the highest root collar growth at age three, and five years which is least in height. On the other way, provenance from Gedeo showed the least root collar diameter growth at three year and there is no consistency growth shown in all provenances in the last five year period. 
In general, in contrary to height growth, provenances from Munessa, and Gedeo, showed vigorous in root collar diameter growth while the least was showed by provenance from Jibat consistently at end observation period. This may be attributed to more or less altitudinal similarity or dissimilarity between Injibara site and the provenances zones.

The correlation coefficients result showed us, There is a significant positive relationship between mean height increment and root collar diameter of Prunus africana seedlings $\mathrm{r}(3)=$ 99, $\mathrm{p}<0.001$. the Table 5 showed that mean root collar diameter growth is positively correlated with height This implies that provenance with largest root collar diameter is the tallest.

Table 5.Correlation coefficient of different traits between provenances

\begin{tabular}{lll}
\hline & Mean height & Mean RCD \\
\hline Mean height & 1.00000 & 0.99539 \\
Mean RCD & $0.99539 *$ & 1.00000 \\
\hline
\end{tabular}

Note: $n s=$ not significant at $(P=0.05), *=$ significant at $P=0.05$.

\section{Discussion}

The findings from this study suggest that P.africana seedlings come from different provenances, may be influenced by their environmental niches, at moderate level. A total of three Prunus africana provenances where collected from three locations(Gedew,jibat and munnessa) their growth performance tested for over 5 years (see figure 1).not only testing of seedling growth performance and survival of the provenances but also the species under Insitu conservation to keep this economically, socially and ecologically important species from disappearance. Because P.africana has great national and international concern and also an icon for saving endangered animals and trees threatened by extinction (Simons, A. J., et al., 1998).

Study approved by Getachew Tesfaye and et al (2011) P.africana seedling growth indicated about $0.56 \mathrm{~cm}$ height increment in 136days period at Munnessa-Shashmene while much greater than from provenances origin about $0.56 \mathrm{~cm}$ recorded at Injibara climate with mountainous, rainy weather comes hail, which is a major problem for the local farmers.

Result indicated us, seedling survival decreased possibly by edged forest canopy shade which few other reports also approved light exposure among the limits on the regeneration of the species.

Moisture one of vital variables which tree seedlings require additional moisture to rainwater in dry areas for their early survival and thereby limits the growth of seedlings during long dry season (Oweis e et al.,t al, 2001; Panda, 2005). However, moisture is may not interesting in 
Injibaras site, because the amount of rainfall in this area is relatively better than other parts of areas, but, moisture still useful in low rainfall areas. Wild apes sheltered from nearby natural forest are among mechanical agents by feeding shoots of the plant which affects seedling growth especially at borders in the early seedling establishment.

Even though, transplantation and cultivation of P.african as medicinal harvest are not as such a common practice in the study area. But the low occurrence of $P$. africana in wild habituates may be due to disturbance caused by mainly expansion of agricultural practices and pressure on natural forest.

\section{Conclusion and recommendation}

In general, the provenances of P.africana did not exhibited significant differences on survival and all growth performance parameters (height, and root collar diameter growth). This may be implied that any of studied provenances of P.africana has no difficulty in establishing itself at injibara site. However, seedling survival and growth might be affected with sun exposure, soil water potential and allelopathic effects (Aceccia decurrence) by nearby A.decurrence dominated forests. Based on the overall performance Jibat, Gedeo, and Munnessa provenances showed a better result indicating that any of these seed zones of P.africana has better suited to establish at injibara site and similar agro ecologies.

The observed survival and growth may qualify Jibat provenance as a potential seed source for establishment of P.africana plantations in North- Western highlands of Amhara Region with similar climatic and ecological condition with Awi area.

In order to make a confidence conclusion as to the genetic variability among provenances, we strongly recommended continuing the observation.Further research is needed to resources, propagation and bark content in wider and detail for proven seed orchard delivery to end users for international trade or bark market.

There is an urgent need to awareness on conservation and sustainable utilization strategy for this plant in close partnership with all relevant stakeholders. Nursery sites establishment, domestication of P.africana as agro forestry tree and distribution of proven seedlings to farmers, planting in the field gene banks and natural forest enrichment with $P$. africana is recommended to save species from disappearance. According to Mohammed and Abe be, 2004 give the vested international demand for the species, domestication and cultivation of the species in Ethiopia, will add P.africana to the list of highly valued plant next to Coffee for national income generation. 


\section{Acknowledgements}

I am grateful to all the Forestry Research Directorate staffs at Adet Agricultural Research Center (AARC), and to Amhara Agricultural Research Institute (ARARAI), for having fully supported this study.

\section{References}

Alvarez-Aquino C, Williams-Linera G, Newton AC 2004. Experimental native tree seedling establishment for the restoration of a Mexican cloud forest. Restoration Ecology

Bane J, Nune S, Mekonen A, Bluffstone R (2008). Policies to increase forest cover in Ethiopia. In: Proceedings of a policy workshop September 2007. Ethiopian Development Research institute, Addis Ababa, Jan 2008

Bekele-Tesemma A, Birnie A, Tengnas B. (1993). Useful trees and shrubs for Ethiopia. Regional Soil Conservation Unit (RSCU), Swedish International Development Authority (SIDA).

Betti,J.L.,(2008). Non-detriment findings report on prunus africana (rosaceae) in Cameroon. WG 1 - Trees Case Study 9,Prunus Africana,Country - CAMEROON Original Language - English

Cunningham, A.B., Mbenkum, F.T.(1993). Sustainability of harvesting Prunus africana bark in Cameroon: a medicinal plant in international trade. People and Plants Working Paper 2. UNESCO, Paris. 
Dawit Abebe (2001). The role of medicinal plants in healthcare coverage of Ethiopia: the possible benefits of integration. In: Conservation and Sustainable Use of Medicinal 61 Plants in Ethiopia, Proceedings of the National workshop, Medhen Zewdu and Abebe Demissie (eds). Institute of Biodiversity Conservation and Research, 7-23

Dawit Abebe and Ahadu Ayehu (1993). Medicinal Plants and Enigmatic Health Practice of Northern Ethiopia. B.S. P.E, Addis Ababa, Ethiopia.

Demel Teketay (1999). Past and present activities, achievements and constrains in forest genetic resources conservation in Ethiopia. In: Forest Genetic Resources Conseravtion on Principles, Strategies and Actions. Proceedings the National Forest Genetic Resources Conservation Strategies Development Workshops, Edward, S., Abebe Demissie, Taye Bekele and Haase, G. (eds). IBCR, Addis Ababa.

Getachew Tesfaye and et al (2011). Seedling growth and survival of indigenous tree species along a light gradient in a dry afromontane forest. In: Forestry: Research, Ecology and Policies, ISBN: 978-1-61209-824-1, Nova Science Publishers, Inc.

K.M. Stewart,(2003). The African cherry (Prunus africana): Can lessons be learned from an over-exploited medicinal tree? Journal of Ethnopharmacology review, Fort Lauderdale, FL, USA.

Mohammed and Abe be, 2004. Unknown.

Negash Mamo and Mebrate Mihretu, 2005. Provenance effect on early survival and growth performance of juniperus procera at jibli, Awi zone. Ethiopian journal of natural resource 7(2) pp 201-216.

Orwa C, Mutua A, Kindt R , Jamnadass R, Simons A.( 2009). Agroforestree Database:a tree reference and selection guide version 4.0 (http://www.worldagroforestry.org/af/treedb/)

Oweis, T., D. Prinz and A.Hachum, 2001. Water Harvesting: Indigenous Knowledge for the Future of the Drier Environments. ICARDA, Aleppo, Syria.42 pp.

Simons, A. J., Dawson, I.K., Duguma, B. and Tchoundjeu, Z., 1998. Passing Problems:

Prostate and Prunus. HerbalGram. The Journal of the American Botanical Council, 40: 45-49.

Tegegne Melese, and et al., (2015). Prevalence of Ovine Lungworm in Banja District, Awi Zone, North West Ethiopia. Acta Parasitologica Globalis. 